\title{
Genetic factors associated with small for gestational age birth and the use of human growth hormone in treating the disorder
}

\author{
Paul Saenger ${ }^{1 *}$ and Edward Reiter ${ }^{2}$
}

\begin{abstract}
The term small for gestational age (SGA) refers to infants whose birth weights and/or lengths are at least two standard deviation (SD) units less than the mean for gestational age. This condition affects approximately 3\%-10\% of newborns. Causes for SGA birth include environmental factors, placental factors such as abnormal uteroplacental blood flow, and inherited genetic mutations. In the past two decades, an enhanced understanding of genetics has identified several potential causes for SGA. These include mutations that affect the growth hormone (GH)/insulin-like growth factor (IGF)-1 axis, including mutations in the IGF-1 gene and acid-labile subunit (ALS) deficiency. In addition, select polymorphisms observed in patients with SGA include those involved in genes associated with obesity, type 2 diabetes, hypertension, ischemic heart disease and deletion of exon 3 growth hormone receptor (d3-GHR) polymorphism. Uniparental disomy (UPD) and imprinting effects may also underlie some of the phenotypes observed in SGA individuals. The variety of genetic mutations associated with SGA births helps explain the diversity of phenotype characteristics, such as impaired motor or mental development, present in individuals with this disorder. Predicting the effectiveness of recombinant human $\mathrm{GH}(\mathrm{hGH})$ therapy for each type of mutation remains challenging. Factors affecting response to $\mathrm{hGH}$ therapy include the dose and method of $\mathrm{hGH}$ administration as well as the age of initiation of hGH therapy. This article reviews the results of these studies and summarizes the success of hGH therapy in treating this difficult and genetically heterogenous disorder.
\end{abstract}

Keywords: Growth hormone, Small for gestational age, Insulin-like growth factor, Acid-labile subunit deficiency, Uniparental disomy

\section{Definition and epidemiology of small for gestational age (SGA)}

Despite past inconsistencies in defining small for gestational age (SGA) (as reviewed by Saenger et al [1]) the International Societies of Pediatric Endocrinology and the Growth Hormone Research Society, as well as the International Small for Gestational Age Advisory Board, recently recommended that the term refer to infants whose birth weights and/or lengths are at least two standard deviation (SD) units less than the mean for gestational age $[2,3]$. According to this definition, approximately $3 \%-$ $10 \%$ of newborns are considered SGA at birth, although it should be noted that new intrauterine growth curves

\footnotetext{
* Correspondence: phsaenger@gmail.com

${ }^{1}$ Albert Einstein College of Medicine, Winthrop University Hospital, 120 Mineola Boulevard, Mineola, NY 13501, USA

Full list of author information is available at the end of the article
}

created with a more contemporary, larger, and more racially diverse population suggest that many SGA patients are often misclassified as appropriate for gestational age (AGA) [4]. While most of these infants undergo catch-up growth, 10\%-15\% remain small for their age at the age of 2 years [5-8]. In 2001, human growth hormone (hGH) therapy using dose regimens up to $48 \mathrm{mcg} / \mathrm{kg} /$ week [3] was approved by the United States (US) Food and Drug Administration (FDA) to treat SGA patients greater than 2 years old. However, because the causes of SGA are diverse, hGH treatment outcomes vary among patients. Thus, identifying the underlying mechanisms for SGA births may help predict patient response to hGH therapy. Causes for SGA births, which are summarized in Table $1[3,4]$, involve environmental factors, placental factors such as abnormal uteroplacental blood flow, or inherited genetic mutations $[3,4]$. Over the last two decades, 
Table 1 Factors associated with increased incidence of SGA birth

\begin{tabular}{|c|c|c|c|}
\hline Fetal & Maternal & Uterine/Placental & Demographic \\
\hline Karyotypic & Medical conditions & Gross structural placental factors & Maternal age \\
\hline -Trisomy 21 & -Hypertension & -Single umbilical artery & -Very young age \\
\hline -Trisomy 18 & -Renal disease & -Placental hemangiomas & -Older age \\
\hline -Monosomy X & -Diabetes mellitus & -Infarcts, focal lesions & Maternal height \\
\hline -Trisomy 13 & -Collagen vascular diseases & Insufficient uteroplacental perfusion & Maternal weight \\
\hline Chromosomal abnormalities & -Maternal hypoxemia & -Suboptimal implantation site & Maternal and paternal race \\
\hline -Autosomal deletion & Infection & Placenta previa & History of SGA \\
\hline -Ring chromosomes & -Toxoplasmosis & Low-lying placenta & \\
\hline Genetic diseases & -Rubella & Placental abruption & \\
\hline -Achondroplasia & -Cytomegalovirus & & \\
\hline -Bloom syndrome & -Herpesvirus & & \\
\hline Congenital anomalies & -Malaria & & \\
\hline -Potter syndrome & -Trypanosomiasis & & \\
\hline \multirow[t]{9}{*}{-Cardiac abnormalities } & $-H I V$ & & \\
\hline & Nutritional status & & \\
\hline & -Low prepregnancy weight & & \\
\hline & -Low pregnancy weight & & \\
\hline & Substance use/abuse & & \\
\hline & -Cigarette smoking & & \\
\hline & -Alcohol & & \\
\hline & -Illicit drugs & & \\
\hline & -Therapeutic drugs & & \\
\hline
\end{tabular}

HIV, human immunodeficiency virus; SGA, small for gestational age.

Reprinted with permission from [3].

significant research related to genetic mutations that influence SGA has been conducted, and this article reviews the results of these studies and summarizes the success of hGH therapy in treating this condition. It should be mentioned at the beginning of this review, however, that the number of genetic variations for any particular gene that has been associated with SGA birth does not necessarily correlate with the number of patients who have this defect. For instance, four different genetic mutations in the distal region of the terminal long arm of chromosome 15 linked with SGA birth size will be described, while only two mutations are illustrated for patients born SGA with Silver-Russell syndrome (SRS). However, this does not mean that SGA patients are two times more likely to have a mutation in the distal region of chromosome 15 than a mutation associated with SRS. Of note, a website from the Growth Genetics Consortium, an international collaboration, gathers all current information about genetic syndromes disrupting the growth hormone and insulin-like growth factor (IGF) axis [9]. Cases reported involve the following genes: GHR, GHRHR, STAT5B, IGF1, IGF2, IGFALS, and IGF1R. Forty-eight cases have been approved for inclusion into the database so far. This paper aims to illustrate the variety of genetic mutations that are associated with SGA births while concurrently describing how other phenotype characteristics of the patient, such as motor or mental development, can vary depending on which mutation was inherited.

\section{Genetic factors influencing SGA GH/IGF-1 axis \\ IGF-1 gene}

Transcription of the gene for IGF-1 is mediated by the binding of pituitary $\mathrm{GH}$ to specific $\mathrm{GH}$ receptors on hepatocytes. The secretion of IGF-1 from the liver then stimulates cell growth (particularly bone) and inhibits secretion of GH from the pituitary [10]. Consequently, mutations of the IGF-1 gene affect growth and GH secretion and have been correlated with SGA births. A homozygous partial deletion of exons 4 and 5 of IGF-1 was observed for one patient born SGA. The mutation truncated the IGF-1 peptide sequence from 70 to 25 amino acids and was followed by an out-of-frame nonsense sequence and stop codon. In addition to growth defects, the patient suffered from bilateral sensorineural deafness and mental retardation, a feature indicating the importance of IGF-1 in central nervous system development [11]. When treated with hGH at a $0.1 \mathrm{U} / \mathrm{kg}$ dose for 4 days, no detectable IGF-1 level could 
be observed in the patient. However, when treated with recombinant human IGF-1 (rhIGF-1) therapy for one year (three months at $40 \mathrm{mcg} / \mathrm{kg} /$ day, nine months at $80 \mathrm{mcg} /$ $\mathrm{kg} /$ day), insulin sensitivity, bone mineral density, and line growth of this patient were improved [12].

A second patient born SGA with sensorineural deafness and mental retardation was evaluated for IGF-1 defects. Investigators observed a $\mathrm{T} \rightarrow \mathrm{A}$ transversion in the $3^{\prime}$-untranslated region of exon 6 that caused the expression of a truncated version of exon 6 and an altered $\mathrm{E}$ domain of the IGF-1 prohormone. hGH therapy for this patient (200 mcg hGH/day intramuscular doses for seven days) afforded no improvement in IGF-1 levels [13]. It should be noted that a second research group later sequenced IGF-1 (exons 1-6) in 53 children born SGA and determined that none of the mutations in the coding region of IGF-1 correlate with SGA stature [14].

Similarly, an IGF-1 defect was observed for a third patient who had initially been evaluated at the age of 21 years for SGA birth size [15]. In addition to SGA size, the patient initially presented with bilateral hearing loss, microcephaly, and severe mental retardation. When investigators reevaluated the patient at 55 years of age, unusually high serum levels of IGF-1 were noted, which varied from the patient phenotypes described by Woods and Bonapace [1113]. Furthermore, both insulin-like growth factor binding protein-3 (IGFBP-3) and insulin-like growth factor-1 receptor (IGF-1R) levels were normal. However, by sequencing $I G F-1$, investigators detected a nucleotide substitution at position $274(\mathrm{G} \rightarrow \mathrm{A})$ in the sequence, which caused an amino acid substitution at position 44 of the IGF-1 protein (V44M). The modified IGF-1 protein displayed a 90-foldlower binding affinity for IGF-1R than the wild-type derivative, although the mutated protein had normal binding capacity for IGFBPs. This reduced affinity of IGF-1 for IGF-1R resulted in diminished phosphorylation of IGF-1R and downstream-acting signaling proteins, particularly Akt/PKB [16,17].

Finally, when a fourth patient born SGA in length and weight was evaluated for IGF-1 defects, investigators discovered a homozygous $\mathrm{G} \rightarrow \mathrm{A}$ missense mutation in the gene that caused replacement of arginine by a glutamine at position 36 (R36Q) in the C domain of the corresponding IGF-1 protein. This change decreased the binding affinity of IGF-1 for IGF-1R by nearly three-fold, but normal affinity for IGFBP-3 was maintained $[18,19]$. This study confirmed that $I G F-1$ mutations that lead to only partial loss of IGF-1 protein activity can cause significant postnatal as well as prenatal growth defects. While highdose hGH therapy (400 mcg/kg/week) promoted successful catch-up growth, the patient's treatment modality was recently changed to rhIGF-1 therapy [20]. It should be noted that rhIGF-1 therapy has only been approved by the US FDA to treat patients with severe primary IGF-1 deficiency or patients with GH gene deletions who have developed neutralizing antibodies to $\mathrm{GH}$ [21]. The genotype-phenotype correlations and response to hGH therapy for each of these patients expressing IGF-1 mutations is summarized in Table 2 [11,13,16-18].

\section{IGF-1R}

Various compound heterozygous mutations throughout the coding sequence of $I G F-1 R$ have been described for multiple families, with each case exhibiting phenotype variations [22]. Typically, IGF-1R mutations can be classified as point mutations or partial deletions. When one patient born SGA with significantly delayed postnatal growth was evaluated for $I G F-1 R$ mutations, investigators determined that two point mutations in exon 2 of $I G F-1 R$ caused two single-base pair substitutions in the codons for amino acid $108(\mathrm{CGG} \rightarrow \mathrm{CAG})$ and $115(\mathrm{AAA} \rightarrow \mathrm{AAC})$ of the corresponding protein. This change resulted in two-thirds-lower binding affinity of IGF-1 to IGF-1R in fibroblasts as compared with controls. When treated with hGH therapy (37.5 $\mathrm{mcg} / \mathrm{kg} /$ week), the patient's growth rate was increased to the 75th percentile for her age [23].

Similarly, a second patient born SGA who suffered from postnatal growth delay, microcephaly, and mild mental retardation was evaluated for IGF-1R mutations.

Table 2 Phenotypic characteristics and response to hGH therapy for patients with IGF-1 mutations

\begin{tabular}{|c|c|c|c|}
\hline Genetic mutation & Phenotype & GH response & Ref. \\
\hline Deletion of exons 4 and 5 & $\begin{array}{l}\text { Birth weight }-3.9 \text { SD; birth length }-5.4 \text { SD; } \\
\text { sensorineural deafness and mental retardation; } \\
\text { nearly undetectable IGF-1 levels }\end{array}$ & - & $\begin{array}{l}\text { Woods, } \\
1996 \text { [11] }\end{array}$ \\
\hline Truncated version of exon 6 & $\begin{array}{l}\text { Birth weight }-4 \text { SD; birth length }-6.5 \text { SD; } \\
\text { sensorineural deafness and mental retardation; } \\
\text { low serum IGF-1 levels }\end{array}$ & - & $\begin{array}{l}\text { Bonapace, } \\
2003 \text { [13] }\end{array}$ \\
\hline$\overline{V 44 M}$ & $\begin{array}{l}\text { Birth weight -3.9 SD score; birth length -4.3 SD score; } \\
\text { bilateral hearing loss, microcephaly, severe mental retardation; } \\
\text { elevated GH levels and IGF-1 levels but normal IGFBP-3 levels }\end{array}$ & n.a. & $\begin{array}{l}\text { Walenkamp } \\
2005[16] \\
\text { Denley, } \\
2005[17]\end{array}$ \\
\hline R36Q & $\begin{array}{l}\text { Birth weight }-2.5 \text { SD score; birth length }-3.7 \text { SD score; } \\
\text { mild mental development delay; reduced IGF-1 levels } \\
\text { but increased IGFBP-3 levels }\end{array}$ & + & $\begin{array}{l}\text { Netchine, } \\
2006 \text { [18] }\end{array}$ \\
\hline
\end{tabular}


A heterozygous point mutation CGA to TGA (Arg59Ter) in exon 2 of $I G F-1 R$ caused early termination of transcription of the IGF-1R protein, leading to reduced receptor expression on the cell surface, as well as decreased autophosphorylation and phosphorylation of signaling proteins [23]. When treated with hGH at 30 $\mathrm{mcg} / \mathrm{kg} /$ day starting at age 6 years, the patient's height increased by 1.01 SD after two years of therapy, indicating that hGH therapy can improve quality of life for SGA patients with this mutation [24].

When 24 children born SGA were evaluated by direct sequencing of $I G F-1 R$ to identify causal mutations, two patients were observed to have a heterozygous missense mutation $(\mathrm{C} \rightarrow \mathrm{T})$ of $I G F-1 R$, which altered the cleavage site of the proreceptor of IGF-1R from RLRR to RLQR (R709Q). This mutation inhibited the expression of mature IGF-1R from the IGF-1R precursor protein. Interestingly, the two patients who presented with this mutation had different levels of mental development. While patient 1 displayed mental retardation, patient 2 had normal intellectual development. Thus, no link exists between the heterozygous $I G F-1 R$ mutation and intellectual development [25].

Similarly, two more patients were evaluated and determined to present with a missense mutation in the intracellular kinase domain of IGF-1R. The older patient, a 35 -year-old mother, showed above-average intelligence and no dysmorphic features, but her height (-4.0 SD score) and head circumference ( -3.0 SD score) showed growth retardation. Her daughter, patient 2, was born SGA and showed normal mental development but delayed motor development by the age of 15 months. Both patients showed increased IGF-1 levels. Sequence analysis of $I G F-1 R$ showed a heterozygous $\mathrm{G} \rightarrow \mathrm{A}$ nucleotide substitution, which changed the amino acid sequence of IGF-1R at position 1050 from glutamic acid to lysine. This mutation did not affect expression of IGF-1R protein, but the sequence alteration reduced autophosphorylation of IGF-1R and activation of PKB/ Akt [26]. Similarly, a 13.6-year-old girl who displayed short stature (-5.0 SD score) and reduced bone age (9.7 years), as well as elevated IGF-1 levels and no improvement in height following six months of treatment with hGH therapy at a daily dose of $70 \mathrm{mcg} / \mathrm{kg} / \mathrm{day}$, was evaluated for IGF-1R mutations. A heterozygous $\mathrm{G} \rightarrow \mathrm{A}$ point mutation at position 1577 of $I G F-1 R$ resulted in substitution of arginine with glutamine at residue 481 of the corresponding protein (R481Q). This mutation altered the $\alpha$-subunit of IGF-1R, leading to reduced phosphorylation and cell growth [27]. Recently, a third report has described a similar IGF-1R mutation in which alanine replaced glycine at position 1125 in seven patients from the same family, causing reduced receptor autophosphorylation and phosphorylation of downstream kinases [28].
Finally, a patient born SGA with high IGF-1 levels who showed only marginal improvement in height following treatment with hGH therapy at the age of 7.4 years (doses ranging from 31 to $36 \mathrm{mcg} / \mathrm{kg} /$ day) was evaluated for $I G F$ $1 R$ mutation. Gene sequencing showed heterozygous $\mathrm{T} \rightarrow \mathrm{A}$ mutation at position 1886, which resulted in substitution of valine with glutamic acid at position 599 of the protein (V599E). This mutation interfered with the receptor trafficking pathway, diminishing the density of the receptor on the cell surface [29]. The genotype-phenotype correlations and response to hGH therapy for each of these patients expressing $I G F-1 R$ point mutations is summarized in Table 3 [23,25-29].

In addition to point mutations, distal deletions of the terminal long arm of chromosome 15 have also been linked to patients born SGA, although these mutations are quite rare. Often, these patients present with symptoms resembling Prader-Willi or Angelman syndrome, two diseases resulting from deletions in the $15 \mathrm{q} 11 \mathrm{q} 13$ region [30]. One patient born SGA who exhibited continued growth retardation at the age of 4.5 years was evaluated for such distal deletion. It was determined that the patient presented with partial monosomy $15 \mathrm{q} 26.2 \rightarrow 15$ qter, correlating to a deleted critical region of approximately 5.7 $\mathrm{Mb}$ [31]. This deletion includes the region $15 \mathrm{q} 26.3$, to which the IGF-1R gene has been assigned [32]. A similar deletion was observed for a patient born SGA who displayed a heterozygous $8.58 \mathrm{Mb}$ deletion in the same region [33]. Similarly, a patient born SGA who showed significant growth retardation by the age of 2 years was evaluated for deletions in chromosome 15. Results indicated that the maternally derived chromosome 15 had a 4.7 $\mathrm{Mb}$ deleted region, which included 15q26.2 [34]. The smallest deletion of chromosome 15 that has been observed to cause SGA birth involves a mutation in exons 11-21 of the $I G F-1 R$ gene (a $0.095 \mathrm{Mb}$ deletion) and was associated with SGA births over three generations in a single family [35]. Typically, patients with partial deletions in this region display mental and psychomotor developmental retardations more often than patients with point $I G F-1 R$ mutations [22].

Fortunately, patients with partial deletions of chromosome 15 respond favorably to hGH treatment. A patient born SGA who displayed a heterozygous loss of $15 \mathrm{q} 26.2 \rightarrow 15$ qter began $\mathrm{hGH}$ treatment at the age of 5.3 years at a dose of $1 \mathrm{mg} / \mathrm{m}^{2} /$ day (approximately 30 $\mathrm{mcg} / \mathrm{kg} /$ day). Rapid growth catch-up was observed, and by the age of 15 years the patient had nearly reached her target height (-1.6 SD score) [36]. Similarly, two patients displaying deletions in exons $1-21$ and exons 3-21 were treated with hGH therapy at a dose of $1 \mathrm{mg} / \mathrm{m}^{2} /$ day (approximately $30 \mathrm{mcg} / \mathrm{kg} /$ day). For both patients, treatment resulted in moderate increase in height of approximately +1 SD after one year [37]. 
Table 3 Phenotypic characteristics and response to hGH therapy for patients with IGF-1R mutations

\begin{tabular}{|c|c|c|c|}
\hline Genetic mutation & Phenotype & GH response & References \\
\hline $\begin{array}{l}\mathrm{R} 108 \mathrm{Q} \\
\mathrm{K} 115 \mathrm{~N}\end{array}$ & $\begin{array}{l}\text { Birth weight }-3.5 \text { SD score; delayed motor skill development; } \\
\text { psychiatric anomalies; normal IGF-1 levels, } \\
\text { delayed motor development }\end{array}$ & + & $\begin{array}{l}\text { Abuzzahab, } \\
2003[23]\end{array}$ \\
\hline R59X & $\begin{array}{l}\text { Birth weight }-3.5 \text { SD score; birth length }-5.8 \text { SD score; } \\
\text { microcephaly, mild retardation, and delayed motor and } \\
\text { speech development; }\end{array}$ & + & $\begin{array}{l}\text { Abuzzahab, } \\
2003[23]\end{array}$ \\
\hline R709Q & $\begin{array}{l}\text { Birth weight }-1.5 \text { SD score; birth length }-1.0 \text { SD score; } \\
\text { significant mental retardation }\end{array}$ & N/A & $\begin{array}{l}\text { Kawashima, } \\
2005[25]\end{array}$ \\
\hline E1050K & $\begin{array}{l}\text { Birth height }-0.3 \text { SD score, birth weight }-2.1 \text { SD score; } \\
\text { height at } 35 \text { years }-4.0 \text { SD score; head circumference at } 35 \text { years } \\
-3.0 \text { SD score; no dysmorphic features; high IGF-1 levels }\end{array}$ & N/A & $\begin{array}{l}\text { Walenkamp, } \\
2006[26]\end{array}$ \\
\hline R481Q & Height -4.9 SD score, reduced bone age, elevated IGF-1 levels & - & $\begin{array}{l}\text { Inagaki, } \\
2007[27]\end{array}$ \\
\hline G1125A & $\begin{array}{l}\text { Birth weight }-1.7 \text { SD score; head circumference at } \\
\text { birth }-3.7 \text { SD score; normal mental development }\end{array}$ & N/A & $\begin{array}{l}\text { Kruis, } \\
2010[28]\end{array}$ \\
\hline V599E & $\begin{array}{l}\text { Birth weight }-2.3 \text { SD score; birth head circumference } \\
<3 \text { rd percentile; high IGF-1 levels; mental retardation }\end{array}$ & - & $\begin{array}{l}\text { Wallborn, } \\
2010[29]\end{array}$ \\
\hline
\end{tabular}

$\mathrm{hGH}$, human growth hormone; IGF-1, insulin-like growth factor-1; N/A, not available; SD, standard deviation.

\section{Acid-Labile Subunit (ALS) Deficiency}

In serum, IGF-1 circulates in complex with IGFBP-3 or IGFBP-5 and an ALS, an 85-kDa glycoprotein that functions to prolong the half-life of the IGF-IGFBP-3/IGFBP-5 binary complex [38]. Sixteen different mutations of the IGFALS gene, located at $16 \mathrm{p} 13.3$ on chromosome 16 , have been observed in patients who presented with reduced postnatal growth. The type of IGFALS gene mutation varies, including missense, nonsense, deletion, duplication and insertion that cause frameshift and premature stop codons, and in-frame duplication mutations, but nearly all of the mutations show autosomal recessive pattern of inheritance and cause defects in the leucine-rich repeat region of the corresponding ALS protein (Table 4) [3947]. All of these mutations result in circulating ALS levels that are barely detectable based on enzyme-linked immunoabsorbent assay, radioimmunoassay, or Western immunoblot assays, indicating that the mutations likely inhibit the corresponding protein from being secreted by the liver or cause the protein to degrade rapidly after secretion. The circulating ALS deficiency results in a severe reduction in IGF-1 and IGFBP-3 levels, insulin insensitivity, and pubertal delay. hGH therapy was initiated for some of these patients in an effort to increase growth rate. However, despite the treatments, ranging in duration from six months to more than two years, very little growth response was observed. However, it has been suggested that hGH therapy may be beneficial for heterozygous carriers who still carry one intact IGFALS allele.

\section{Select polymorphisms}

Obesity and diabetes

For many individuals born SGA, health concerns such as obesity, type 2 diabetes, hypertension, and ischemic heart disease are often encountered later in life [48-50]. In one study, DNA samples from 546 patients (227 children born SGA and 319 born AGA) were analyzed for 54 single nucleotide polymorphisms (SNPs) associated with diabetes or obesity. Genetic variations in five of these SNPs (KCNJ11, BDNF,

Table 4 Genetic mutations involved in ALS deficiency [39-47]

\begin{tabular}{|c|c|c|}
\hline Genetic mutation & Type of mutation & Homozygous/Heterozygous \\
\hline E35KfsX87 & $\begin{array}{l}\text { Frameshift, } \\
\text { premature stop } \\
\text { codon }\end{array}$ & Homozygous \\
\hline$\overline{E l 35 G f s \times 17}$ & $\begin{array}{l}\text { Frameshift, } \\
\text { premature stop } \\
\text { codon }\end{array}$ & Heterozygous \\
\hline $\mathrm{C} 60 \mathrm{~S}$ & Missense & Compound heterozygous \\
\hline P73L & Missense & Homozygous \\
\hline L134Q & Missense & Homozygous \\
\hline $\mathrm{L} 172 \mathrm{~F}$ & Missense & Homozygous \\
\hline A183SfsX149 & $\begin{array}{l}\text { Frameshift, } \\
\text { premature stop } \\
\text { codon }\end{array}$ & Compound heterozygous \\
\hline S195_R197dup & $\begin{array}{l}\text { In-frame insertion of } \\
3 \text { amino acids, SLR }\end{array}$ & Compound heterozygous \\
\hline L241P & Missense & Compound heterozygous \\
\hline L244F & Missense & Compound heterozygous \\
\hline N276S & Missense & Homozygous \\
\hline Q320X & Nonsense & Homozygous \\
\hline L437_L439dup & $\begin{array}{l}\text { In-frame insertion of } \\
3 \text { amino acids, LEL }\end{array}$ & Homozygous \\
\hline $\mathrm{D} 440 \mathrm{~N}$ & Missense & Homozygous \\
\hline L497FfsX40 & $\begin{array}{l}\text { Frameshift, } \\
\text { premature stop } \\
\text { codon }\end{array}$ & Homozygous \\
\hline C540R & Missense & Compound heterozygous \\
\hline
\end{tabular}

ALS, acid-labile subunit. 
PFKP, PTER, and SEC16B) correlated with SGA size. Therefore, genetic factors that contribute to obesity and type 2 diabetes likely correlate with SGA [51].

\section{Angiotensinogen gene variants}

Angiotensinogen (AGT) is an $\alpha 2$-globulin precursor to angiotensin II that regulates blood pressure and overall homeostasis [52]. In one study, 174 women and their 162 infants born SGA were compared with 400 women and their 240 infants born AGA. The study evaluated these individuals for a methionine to threonine substitution at codon 235 (235Met $>$ Thr) in the AGT gene, a mutation associated with pregnancy complications such as preeclampsia [53]. The results showed a higher frequency of the 235Thr allele in both mothers (0.60 for SGA versus 0.36 for controls) and infants (0.59 for SGA versus 0.38 for controls) who were associated with SGA births [54]. However, the mechanism by which the 235Met $>$ Thr mutation affects maternal-placental and fetal-placental circulation and, consequently, fetal growth is not understood. Interestingly, a prior study found no correlation between this polymorphism and an increased risk of SGA birth. The differences between the findings of the two investigations were attributed, in part, to variation in ethnic diversity between the two study groups [55].

\section{Deletion of exon 3 growth hormone receptor (d3-GHR)}

The $d 3-G H R$ polymorphism, a $2.7 \mathrm{kB}$ deletion in exon 3 of the GHR gene, is a common genetic defect in individuals with normal height and those born SGA [56]. However, for patients born SGA, the $d 3-G H R$ polymorphism has been investigated as a potential mutation that affects hGH therapy due to its role in $\mathrm{GH}$ signaling. When response to hGH therapy was compared between children born SGA who had only full-length $G H R$ versus at least one $d 3-G H R$ allele, results showed that patients with the $d 3-G H R$ polymorphism responded 1.7 to 2 times better to hGH therapy than patients with only the full-length gene [57]. Similarly, SGA patients with either two full-length GHRs (fl/fl) or one $(\mathrm{d} 3 / \mathrm{fl})$ or two $(\mathrm{d} 3 / \mathrm{d} 3) \mathrm{d} 3-\mathrm{GHR}$ alleles were administered hGH for 12 months at a mean dose of $56 \pm 11 \mathrm{mcg} / \mathrm{kg} /$ day. At the end of 12 months, carriers of either one or two $d 3$ GHR alleles were observed to respond slightly better to hGH therapy than patients with two full-length alleles, although the difference was not statistically significant. The authors suggested that response to hGH therapy for patients with this mutation depends on the specific causes of short stature, such as IGF-1 insensitivity or IGF-1 deficiency [58]. Consequently, children born SGA with the d3-GHR mutation appear to be prime candidates for hGH therapy, although these results are still controversial.

For instance, a comparison was made between the GHR genotype (ie, $\mathrm{fl} / \mathrm{fl}, \mathrm{d} 3 / \mathrm{fl}$, or $\mathrm{d} 3 / \mathrm{d} 3$ ) of patients with $\mathrm{GH}$ deficiency and the individual's response to hGH treatment.
Patients were treated with hGH at a mean dose of $0.2 \mathrm{mg} /$ $\mathrm{kg} /$ week for one year and then evaluated for height SD score, height velocity, and height velocity SD score. No statistically significant difference with respect to the measured outcomes could be observed between the patients with the $d 3-G H R$ allele and patients who were homozygous for the full-length GHR. Furthermore, this study observed that there was no relationship between an individual's baseline phenotype and his/her GHR genotype, suggesting that the $d 3-G H R$ allele does not affect height in GH deficiency [59]. This lack of correlation between $d 3-$ GHR genotype and response to hGH treatment was also confirmed in studies for patients born SGA [60,61].

Recently, a meta-analysis of 15 studies investigating the effects of $d 3-G H R$ genotype and a patient's first-year response to hGH therapy, including height gain and change in growth velocity, was conducted. The results of this analysis indicated that patients with the $d 3-G H R$ allele showed improved growth velocity when treated with hGH therapy, but the treatment outcome was affected by the dose (low doses of hGH showed best response) and age at time of treatment (older patients responded more favorably). It should be noted, however, that this meta-analysis did not discriminate with respect to the cause of short stature [62]. In a recent 3-year review, Doerr et al conclude that the determination of GHR isoforms for deletion of exon 3 is not particularly useful in defining the overall response to $\mathrm{GH}$ in short SGA children [63].

\section{Uniparental disomy (UPD) and imprinting effects}

UPD is a process whereby a person inherits two copies of a gene or chromosome from one parent and no copies from the other parent. In most cases, UPD does not affect fetal development. However, if a UPD gene is also an imprinted gene, there may be adverse effects to the fetus, because UPD of imprinted genes is equivalent to functional nullisomy [64]. The transcriptional regulation of imprinted genes varies from normal genes in that imprinted genes are only active from one parent allele. For instance, a gene may be active only when paternally inherited; the maternal allele of this gene is "switched off." Conversely, imprinted genes can be maternally expressed and paternally imprinted [65]. Thus, if a patient inherits two versions of an imprinted gene (eg, two copies of a maternal, "switched-off" gene), phenotype abnormalities may result. Studies have indicated that several UPDs can be responsible for short stature in patients born SGA.

\section{SRS}

SRS is a disorder characterized by reduced birth weight, facial features including triangular shape and pointed chin, and body asymmetry [66,67]. Growth restrictions continue through life and often correlate with fasting 
hypoglycemia [68]. hGH treatment, given daily as subcutaneous injections at a dose of $35 \mathrm{mcg} / \mathrm{kg} /$ day for up to three years, is usually suggested for these patients [69].

The genetic causes of SRS vary, with cases of autosomal-dominant, autosomal-recessive, and X-linked inheritance all observed (as reviewed by Hitchins and Abu-Amero) [68,70]. However, the most referenced causal candidates for this disease involve mutations on chromosomes 7 and 11, which both contain groups of genes that undergo genomic imprinting [68]. Since the early 1990s, maternal uniparental disomy 7 (mUPD7), both full mUPD7 and mUPD for the long arm of chromosome 7, were documented to be the cause of SRS in approximately $10 \%$ of cases [71]. However, the phenotype of an SRS patient presenting UPD7 cannot be predicted, as the exact etiology of the mutation varies [72]. Polymerase chain reaction with microsatellite repeat markers or Southern blot analysis with variable number of tandem repeats can effectively be used to screen patients for mUPD7 [73].

In addition to mUPD7, the imprinted region on chromosome 11p15 has been associated with SRS in up to $65 \%$ of patients. Specifically, hypomethylation at the imprinting center region 1 (ICR1) was associated with fetal growth retardation in SRS patients (Figure 1) $[74,75]$. Generally, the ICR1 region regulates the expression of IGF2 and H19, and loss of methylation of this region is associated with approximately $50 \%$ of SRS cases [68]. However, an inherited duplication $(0.76-1 \mathrm{Mb})$ in the ICR 2 domain of $11 \mathrm{p} 15$ has also been shown to be involved in the etiology of SRS. The duplicated region included the maternally expressed genes KCNQ1, CDKN1C, TSSC5/SLC22A8 and TSSC3/PHDLA2 and the paternally expressed gene LIT1 [76]. It should be noted, however, that the distribution of methylation

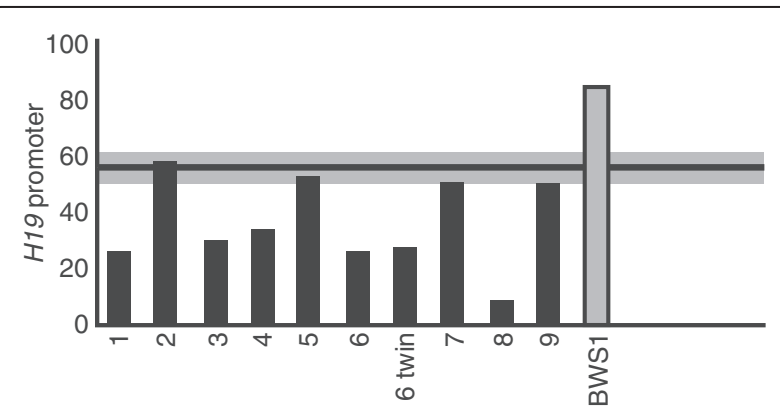

Figure 1 Quantitative representation of methylation indices for H19-IGF2 ICR1 in individuals with SRS (individuals 1-9 and individual 6's twin) and an individual with isolated hypermethylation of the $\mathrm{H} 19$ promoter (BWS1). Five individuals with SRS displayed partial loss of H19-IGF2 ICR1, indicated by the bar below the shaded area near 50\%. SRS, Silver-Russell syndrome. Reprinted from [74] with permission from Macmillan Publishers Ltd; copyright 2005 . values among patients with SRS is quite varied, making clinical diagnosis of the disease based on methylation analysis difficult [77]. In general, use of hGH has become a standard treatment regimen for patients with SRS, despite the limited number of evaluations regarding the effectiveness of this treatment [78].

\section{$m U P D$}

UPD of the long arm of chromosome 14 (UPD14) has been associated with both below-average growth and mental retardation. Initially, it was not known whether the congenital anomalies present in UPD14 patients resulted from an extra copy of an active imprinted gene (ie, two genes that were "switched on") or the absence of gene expression caused by the presence of two repressed alleles (ie, two genes "switched off"). To determine the likely cause of the phenotype, patients with distal partial trisomy for chromosome 14 (Ts14) were evaluated to determine genotype-phenotype correlations to determine whether the partial trisomy was of maternal or paternal origin. By investigating patients with an extra copy of either maternally inherited or paternally inherited copies of chromosome 14, the investigators hoped to observe more pronounced effects of the disease if it was caused by active imprinted genes. All 13 patients with distal maternal Ts14 (mTs14) were born SGA. Conversely, over half of the patients with paternal Ts14 (pTs14) were born at weights AGA, indicating that an absence of paternal information likely causes growth retardation in patients with UPD14. The minimum trisomic regions 14q31.114qter and $14 \mathrm{q} 24.3-14 q$ ter were identified as possibly containing the imprinted genes [79]. Overall, the phenotype of patients with mUPD14 can be quite variable. A review of 24 cases of patients displaying mUPD14 attributes the growth retardation of these patients to confined placental mosaicism and imprinted genes that cause early skeletal maturation, although unusual phenotypes may also be caused by autosomal, recessively inherited mutations [80].

\section{hGH treatment for SGA}

Much research has correlated genetic mutations with SGA births, but the ability to predict the effectiveness of hGH therapy for each mutation remains controversial. Table 5 summarizes the various mutations that have been shown to cause SGA and the likelihood that hGH therapy will promote growth for individuals with these mutations $[11,13,16-18,23,25-29,39-47,51,53-55,57-62,68,70,74-76,78-$ 80]. Some patients with IGF-1 mutations have shown positive growth catch-up when treated with hGH therapy, while others have shown better response to rhIGF-1 therapy. Alternatively, the response to hGH therapy for patients with $I G F-1 R$ mutations appears to correlate with the type of mutation; patients with distal deletions of the 
Table 5 Summary of known genetic causes of SGA and the correlating response to hGH therapy $[11,13,16-18,23$, 25-29,39-47,51,53-55,57-62,68,70,74-76,78-80]

\begin{tabular}{|c|c|c|}
\hline Class of genetic mutation & Specific genetic variant & Response to hGH therapy \\
\hline \multirow{5}{*}{ GH/IGF-1 axis } & IGF-1 & Generally not effective \\
\hline & $I G F-1 R$ & \multirow{3}{*}{$\begin{array}{l}\text { Good for partial distal deletions; } \\
\text { generally not effective for } \\
\text { point mutations }\end{array}$} \\
\hline & Point & \\
\hline & Distal & \\
\hline & ALS deletions & Good outcome for heterozygous carriers \\
\hline \multirow{3}{*}{ Select Polymorphisms } & Obesity/diabetes-related genes & Unclear \\
\hline & Angiotensinogen gene & Unclear \\
\hline & $d 3-G H R$ & Good outcome, but dose and age matter \\
\hline \multirow{6}{*}{ UPD/imprinting effects } & SRS & \multirow{5}{*}{$\begin{array}{l}\text { hGH therapy is commonly used for SRS, } \\
\text { but correlation between effectiveness } \\
\text { and specific genetic mutation has not } \\
\text { been carefully evaluated }\end{array}$} \\
\hline & Full mUPD7 & \\
\hline & mUPD7 for long arm of chromosome 7 & \\
\hline & Hypomethylation at ICR1 on 11p15 & \\
\hline & Duplication of ICR2 on 11p15 & \\
\hline & UPD14 & Unclear \\
\hline
\end{tabular}

ALS, acid-labile subunit; ICR, imprinting control region; IGF-1, insulin-like growth factor-1; d3-GHR, deletion of exon 3 growth hormone receptor; hGH, human growth hormone; SGA, small for gestational age; SRS, Silver-Russell syndrome; UPD, uniparental disomy.

IGF-1R gene generally have improved GH-induced catchup growth as compared with patients who have $I G F-1 R$ point mutations. Finally, the ability to predict the effectiveness of hGH treatment depending on the specific disease (eg, children with SRS versus children with UPD14) has not been thoroughly reviewed, possibly because a significant number of patients born SGA who undergo hGH therapy are never genetically diagnosed. However, despite the controversies, clinical studies have successfully elucidated some trends about hGH treatment on growth in children born SGA (as reviewed by Simon et al [81] and Saenger et al [1]).

The rate of catch-up growth promoted by hGH therapy in patients born SGA correlates with the dose; higher doses typically afford rapid height increase, although a similar response can be achieved using lower doses for a longer time. For instance, a height gain of 2 SD was achieved for patients born SGA using doses of either $67 \mathrm{mcg} / \mathrm{kg} /$ day over 2.5 years or $33 \mathrm{mcg} / \mathrm{kg} /$ day over 5.5 years (Figure 2A) [82]. However, the low-dose regimen requires three times as many injections and $50 \%$ more hGH overall than the high-dose method. The method of administration of hGH therapy can also affect height gain, though less significantly than dose. Patients who received discontinuous high-dose hGH therapy (67 $\mathrm{mcg} / \mathrm{kg} /$ day for one or two years) have shown slightly increased height gain compared with patients receiving a continuous low-dose regimen $(33 \mathrm{mcg} / \mathrm{kg} /$ day doses for three or four years), although discontinuation of the treatment typically corresponds with reduction in growth velocity [83]. A similar trend was observed previously by De Zeghers et al, who found that after six years,

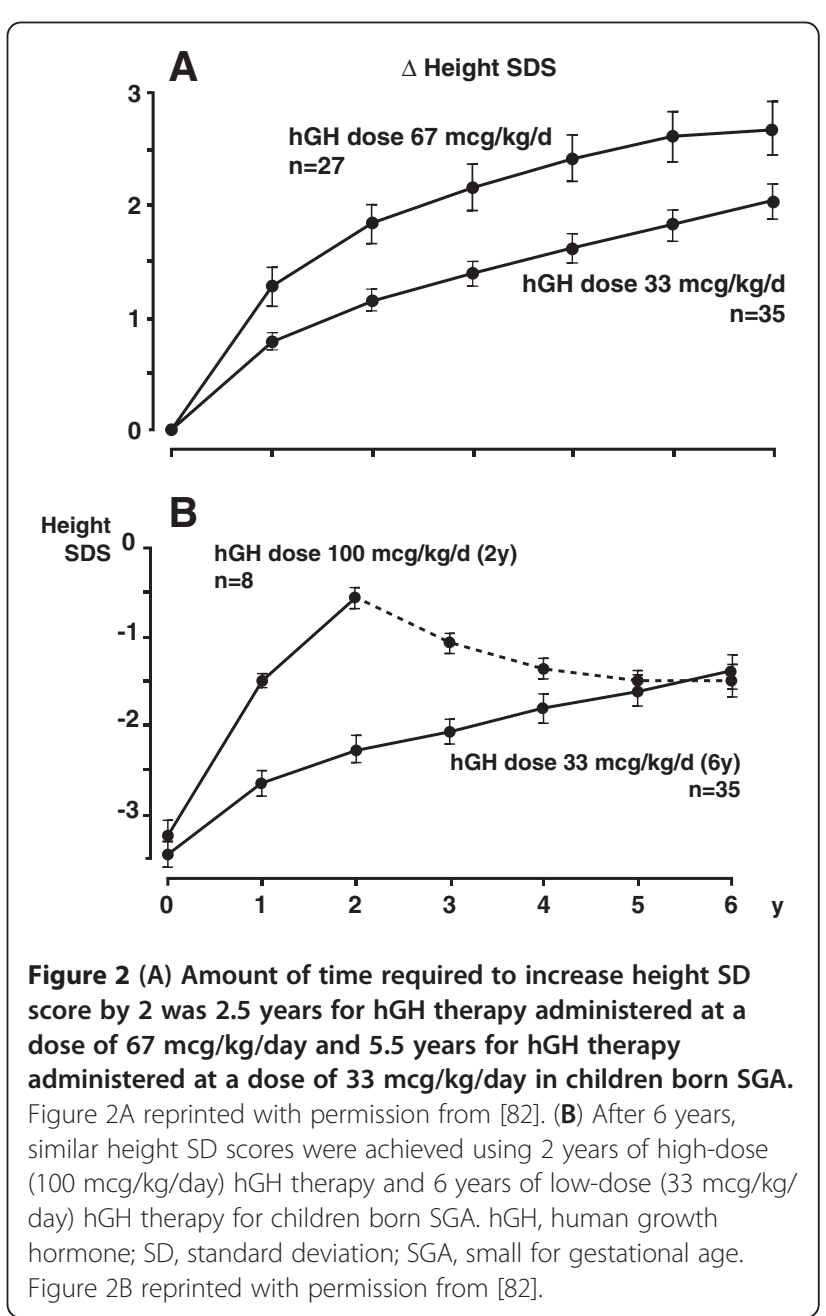


height SD scores were similar for high-dose hGH course for two years and continuous low-dose hGH treatment for six years (Figure 2B) [82]

In addition to the dose and method of administration, the age of initiation of hGH therapy significantly affects the outcome. Patients treated before the onset of puberty achieve optimal results. A recent study showed that children treated for one year with hGH therapy before the age of 4 years achieved greater height gain (1.7 SD score, $12.5 \mathrm{~cm}$ ) than those treated after 4 years of age (1.2 SD score) [84]. Even among older patients, this trend persists. Patients receiving hGH therapy more than two years before puberty showed increased height gain $(1.7 \mathrm{SD}, \sim 12 \mathrm{~cm})$ compared with patients treated fewer than two years before puberty $(0.9 \mathrm{SD}$ gain, $6 \mathrm{~cm})$. However, nearly $90 \%$ of these patients achieved adult height within the normal range [85]. Conversely, patients treated during puberty achieved height gain of only 0.6 SD score, and fewer than $50 \%$ of these patients achieved normal adult height [86].

In 2003, Ranke et al developed a model that essentially summarized the trends that we have described and that could be used by physicians to individualize hGH treatment for SGA patients. Using a pharmacoepidemiological survey of 613 children, various trends were elucidated. In fact, the model could be used to explain approximately $50 \%$ of the variability associated with hGH therapy response during the first and second years of treatment. Nearly $35 \%$ of the variability could be attributed to the dose, followed by the patient's age at the start of treatment. Subsequent growth during the second year of treatment could be predicted based on a successful first year of treatment [87].

It must be mentioned, though not stressed, that some controversy regarding the use of hGH arose in 2011 due to results from a study conducted in France, the Santé Adulte GH Enfant (SAGhE) study. The results from this study indicated that long-term use of hGH in children with short stature could increase a patient's risk of death [88]. The SAGhE study reported that hGH therapy, when administered to patients at doses above $50 \mathrm{mcg} / \mathrm{kg} / \mathrm{day}$, increased the risk of death by $30 \%$ as compared to the general population in France. This effect was attributed to an increased likelihood of bone-tumor formation, cardiovascular disease, and cerebrovascular events. These results concerned patients born SGA, as the normal recommended dose of hGH therapy can be approximately 70 $\mathrm{mcg} / \mathrm{kg} /$ day (Table 6) [1]. However, recent publications and an FDA report have noted flaws associated with the SAGhE study design [88-90]. In many other long-term evaluations of large groups of patients undergoing hGH therapy, the overall safety profile is favorable [91-95]. No increased risk of death due to leukemia, cancer, or cardiovascular disorders was observed.
Table 6 Use of hGH therapy in SGA children in the United States and Europe

\begin{tabular}{lll}
\hline & $\begin{array}{l}\text { FDA-approved } \\
\text { indication in 2001 }\end{array}$ & $\begin{array}{l}\text { EMEA-approved } \\
\text { indication in 2003 }\end{array}$ \\
\hline $\begin{array}{l}\text { Age at start of } \\
\text { treatment (year) }\end{array}$ & 2 & 4 \\
\hline $\begin{array}{l}\text { Height SDS } \\
\text { at start }\end{array}$ & Not stated & -2.5 SD \\
\hline $\begin{array}{l}\text { Growth velocity } \\
\text { before treatment }\end{array}$ & No catch-up growth & Less than 0 SD for age \\
\hline $\begin{array}{l}\text { Reference to } \\
\text { midparental }\end{array}$ & Not stated & Height SDS > 1 SD below \\
height & & midparental height SDS \\
\hline $\begin{array}{l}\text { Dose } \\
\text { (mcg/kg/day) }\end{array}$ & 70 & 35 \\
\hline
\end{tabular}

FDA, United States Food and Drug Administration; EMEA, European Agency for the Evaluation of Medicinal Products; $\mathrm{hGH}$, human growth hormone; SDS standard deviation score; SGA, small for gestational age.

Reprinted with permission from [1]

\section{Conclusions}

Based on results from more than 20 years of research, numerous genetic causes for SGA births have been realized. Genetic defects in either IGF-1 or IGF-1R that result in SGA size typically correlate with phenotypical features such as microcephaly and mental retardation. The most predictive factors for $I G F-1 R$ deletion include small birth size, head size, and stature, as well as high IGF-1 levels, developmental delay, and micrognathia. hGH therapy in patients with mutations in IGF-1 has shown moderate success. Furthermore, for patients with IGF-1R mutations, hGH treatment has been shown to be especially promising, particularly for those with distal deletions of the terminal long arm of chromosome 15. Overall, in studies in which the genotype of SGA patients was not known and hGH therapy was conducted, improvements were observed for most of the patient population, particularly if therapy was begun at a young age.

However, despite these positive results, a number of questions regarding the effectiveness of the treatment remain. For instance, hGH therapy for children with SRS has shown positive results, but overall the improvements are often not statistically significant. Furthermore, the differences in SGA patient response to hGH therapy are still only slightly understood. While much of the diversity in response rates to hGH therapy for SGA patients correlates with the type of genetic mutation, the role of additional factors, such as ethnicity, on this treatment still requires significant research.

\section{Abbreviations}

(AGA): Appropriate for gestational age; (AGT): Angiotensinogen; (ALS): Acid-labile subunit; (FDA): Food and Drug Administration; (GH): Growth hormone; (ICR1): Imprinting center region 1; (IGFBP-3): Insulin-like growth factor binding protein-3; (IGF): Insulin-like growth factor; (IGF-1R): Insulin-like growth factor-1 receptor; (mUPD7): Maternal uniparental disomy 7; (hGH): Recombinant human GH; (rhlGF-1): Recombinant human IGF-1; (SAGhE): Santé Adulte GH Enfant study; (SGA): Small for gestational age; 
(SD): Standard deviation; (SRS): Silver-Russell syndrome; (Ts14): Trisomy for chromosome 14; (UPD): Uniparental disomy; (US): United States.

\section{Competing interests}

Dr. Saenger reports that he receives grant support from Novo Nordisk Inc., and that he is a consultant for LG and Biopartners. Dr. Reiter reports that he has received payment from Novo Nordisk Inc. for board membership; from Abbott Pharmaceuticals as a consultant; from Quintiles for development of educational presentations, and from various pharmaceutical companies for lectures, including service on speakers bureaus.

\section{Authors' contributions}

The authors contributed equally to this work and were involved in the development of its concept, outline, and narrative. At all stages, the authors discussed the data presented and commented on the manuscript. Both authors read and approved the final manuscript.

\section{Acknowledgments}

The authors would like to thank Meredith A. Mintzer, PhD, and Emma Hitt, PhD, of MedVal Scientific Information Services, LLC, for providing medical writing and editorial assistance. This manuscript was prepared according to the International Society for Medical Publication Professionals' Good Publication Practice for Communicating Company-Sponsored Medica Research: The GPP2 Guidelines. Funding to support the preparation of this manuscript was provided by Novo Nordisk Inc

\section{Author details}

${ }^{1}$ Albert Einstein College of Medicine, Winthrop University Hospital 120 Mineola Boulevard, Mineola, NY 13501, USA. 'Baystate Children's Hospital, Tufts University School of Medicine, 759 Chestnut StreetSpringfield, MA 01199 , USA

Received: 6 October 2011 Accepted: 19 March 2012 Published: 15 May 2012

\section{References}

1. Saenger $P$, Czernichow $P$, Hughes I, Reiter EO: Small for gestational age: short stature and beyond. Endocr Rev 2007, 28(2):219-251.

2. Clayton PE, Cianfarani S, Czernichow P, Johannsson G, Rapaport R, Rogol A Management of the child born small for gestational age through to adulthood: a consensus statement of the International Societies of Pediatric Endocrinology and the Growth Hormone Research Society. J Clin Endocrinol Metab 2007, 92(3):804-810.

3. Lee PA, Chernausek SD, Hokken-Koelega AC, Czernichow P: Internationa Small for Gestational Age Advisory Board consensus development conference statement: management of short children born small for gestational age, April 24-October 1, 2001. Pediatrics 2003, 111(6 Pt 1):1253-1261

4. Arya AD: Small for gestation and growth hormone therapy. Indian J Pediatr 2006, 73(1):73-78

5. Rapaport R, Tuvemo T: Growth and growth hormone in children born small for gestational age. Acta Paediatr 2005, 94(10):1348-1355.

6. Hediger ML, Overpeck MD, Maurer KR, Kuczmarski RJ, McGlynn A, Davis WW: Growth of infants and young children born small or large for gestational age: findings from the Third National Health and Nutrition Examination Survey. Arch Pediatr Adolesc Med 1998, 152(12):1225-1231.

7. Karlberg J, Albertsson-Wikland K: Growth in full-term small-for-gestationa -age infants: from birth to final height. Pediatr Res 1995, 38(5):733-739.

8. Hokken-Koelega AC, De Ridder MA, Lemmen RJ, Den Hartog H, De Muinck Keizer-Schrama SM, Drop SL: Children born small for gestational age: do they catch up? Pediatr Res 1995, 38(2):267-271.

9. The Growth Genetics Consortium. Available at: http://umw.growthgeneticsconsortium. org/index.html. Accessed February 15, 2012.

10. Le Roith D: Seminars in medicine of the Beth Israel Deaconess Medical Center. Insulin-like growth factors. N Engl J Med 1997, 336(9):633-640.

11. Woods KA, Camacho-Hubner C, Savage MO, Clark AJ: Intrauterine growth retardation and postnatal growth failure associated with deletion of the insulin-like growth factor I gene. N Engl J Med 1996, 335(18):1363-1367.
12. Woods KA, Camacho-Hubner C, Bergman RN, Barter D, Clark AJ, Savage MO: Effects of insulin-like growth factor I (IGF-I) therapy on body composition and insulin resistance in IGF-I gene deletion. J Clin Endocrinol Metab 2000, 85(4):1407-1411.

13. Bonapace $G$, Concolino D, Formicola S, Strisciuglio P: A novel mutation in a patient with insulin-like growth factor 1 (IGF1) deficiency. J Med Genet 2003, 40(12):913-917.

14. Coutinho DC, Coletta RR, Costa EM, Pachi PR, Boguszewski MC, Damiani D, Mendonca BB, Arnhold IJ, Jorge AA: Polymorphisms identified in the upstream core polyadenylation signal of IGF1 gene exon 6 do not cause pre- and postnatal growth impairment. J Clin Endocrinol Metab 2007, 92(12):4889-4892.

15. van Gemund JJ, Laurent de Angulo MS, van Gelderen HH: Familial prenatal dwarfism with elevated serum immuno-reactive growth hormone levels and end-organ unresponsiveness. Maandschr Kindergeneeskd 1970, 37(11):2-382.

16. Walenkamp MJ, Karperien M, Pereira AM, Hilhorst-Hofstee $Y$, van Doorn J, Chen JW, Mohan S, Denley A, Forbes B, van Duyvenvoorde HA, van Thiel SW, Sluimers CA, Bax JJ, de Laat JA, Breuning MB, Romijn JA, Wit JM: Homozygous and heterozygous expression of a novel insulin-like growth factor-I mutation. J Clin Endocrinol Metab 2005, 90(5):2855-2864

17. Denley A, Wang CC, MCNeil KA, Walenkamp MJ, van DH, Wit JM, Wallace JC, Norton RS, Karperien M, Forbes BE: Structural and functional characteristics of the Val44Met insulin-like growth factor I missense mutation: correlation with effects on growth and development. Mol Endocrinol 2005, 19(3):711-721.

18. Netchine I, Azzi S, Houang M, Seurin D, Perin L, Ricort JM, Daubas C, Legay C, Mester J, Herich R, Godeau F, Le Bouc Y: Partial IGF-1 deficiency demonstrates the critical role of IGF-1 in growth and brain development. [abstract]. Horm Res 2006, 65(suppl 4):29.

19. Netchine I, Azzi S, Houang M, Seurin D, Perin L, Ricort JM, Daubas C, Legay C, Mester J, Herich R, Godeau F, Le Bouc Y: Partial primary deficiency of insulin-like growth factor (IGF)-I activity associated with IGF1 mutation demonstrates its critical role in growth and brain development. J Clin Endocrinol Metab 2009, 94(10):3913-3921.

20. Netchine I, Azzi S, Le Bouc Y, Savage MO: IGF1 molecular anomalies demonstrate its critical role in fetal, postnatal growth and brain development. Best Pract Res Clin Endocrinol Metab 2011, 25(1):181-190.

21. Graul Al, Prous JR: The year's new drugs. Drug News Perspect 2006, 19 (1):33-53.

22. Klammt J, Kiess W, Pfaffle R: IGF1R mutations as cause of SGA. Best Pract Res Clin Endocrinol Metab 2011, 25(1):191-206.

23. Abuzzahab MJ, Schneider A, Goddard A, Grigorescu F, Lautier C, Keller E, Kiess W, Klammt J, Kratzsch J, Osgood D, Pfaffle R, Raile K, Seidel B, Smith RJ, Chernausek SD: IGF-I receptor mutations resulting in intrauterine and postnatal growth retardation. N Engl J Med 2003, 349(23):2211-2222.

24. Raile K, Klammt J, Schneider A, Keller A, Laue S, Smith R, Pfaffle R, Kratzsch J, Keller $\mathrm{E}$, Kiess W: Clinical and functional characteristics of the human Arg59Ter insulin-like growth factor i receptor (IGF1R) mutation: implications for a gene dosage effect of the human IGF1R. J Clin Endocrinol Metab 2006, 91(6):2264-2271.

25. Kawashima Y, Kanzaki S, Yang F, Kinoshita T, Hanaki K, Nagaishi J, Ohtsuka Y, Hisatome I, Ninomoya H, Nanba E, Fukushima T, Takahashi S: Mutation at cleavage site of insulin-like growth factor receptor in a short-stature child born with intrauterine growth retardation. J Clin Endocrinol Metab 2005, 90(8):4679-4687

26. Walenkamp MJ, van der Kamp HJ, Pereira AM, Kant SG, van Duyvenvoorde HA, Kruithof MF, Breuning MH, Romijn JA, Karperien M, Wit JM: A variable degree of intrauterine and postnatal growth retardation in a family with a missense mutation in the insulin-like growth factor I receptor. J Clin Endocrinol Metab 2006, 91(8):3062-3070.

27. Inagaki K, Tiulpakov A, Rubtsov P, Sverdlova P, Peterkova V, Yakar S, Terekhov S, LeRoith D: A familial insulin-like growth factor-I receptor mutant leads to short stature: clinical and biochemical characterization. $J$ Clin Endocrinol Metab 2007, 92(4):1542-1548.

28. Kruis T, Klammt J, Galli-Tsinopoulou A, Wallborn T, Schlicke M, Muller E, Kratzsch J, Korner A, Odeh R, Kiess W, Pfaffle R: Heterozygous mutation within a kinase-conserved motif of the insulin-like growth factor I 
receptor causes intrauterine and postnatal growth retardation. J Clin Endocrinol Metab 2010, 95(3):1137-1142.

29. Wallborn T, Wuller S, Klammt J, Kruis T, Kratzsch J, Schmidt G, Schlicke M, Mulle E, van de Leur HS, Kiess W, Pfaffle R: A heterozygous mutation of the insulinlike growth factor-I receptor causes retention of the nascent protein in the endoplasmic reticulum and results in intrauterine and postnatal growth retardation. J Clin Endocrinol Metab 2010, 95(5):2316-2324.

30. Knoll JH, Nicholls RD, Magenis RE, Graham JM Jr, Lalande M, Latt SA: Angelman and Prader-Willi syndromes share a common chromosome 15 deletion but differ in parental origin of the deletion. Am J Med Genet 1989, 32(2):285-290.

31. Pinson L, Perrin A, Plouzennec C, Parent P, Metz C, Collet M, Le Bris MJ, Douet-Guilbert N, Morel F, de Braekeleer M: Detection of an unexpected subtelomeric $15 q 26.2$ - > qter deletion in a little girl: clinical and cytogenetic studies. Am J Med Genet A 2005, 138A(2):160-165.

32. Peoples $R$, Milatovich A, Francke U: Hemizygosity at the insulin-like growth factor I receptor (IGF1R) locus and growth failure in the ring chromosome 15 syndrome. Cytogenet Cell Genet 1995, 70(3-4):228-234

33. Choi JH, Kang M, Kim GH, Hong M, Jin HY, Lee BH, Park JY, Lee SM, Seo EJ, Yoo HW: Clinical and functional characteristics of a novel heterozygous mutation of the IGF1R gene and IGF1R haploinsufficiency due to terminal 15q26.2-> qter deletion in patients with intrauterine growth retardation and postnatal catch-up growth failure. J Clin Endocrinol Metab 2011, 96(1):E130-E134.

34. Rujirabanjerd S, Suwannarat W, Sripo T, Dissaneevate P, Permsirivanich W, Limprasert $P$ : De novo subtelomeric deletion of $15 q$ associated with satellite translocation in a child with developmental delay and severe growth retardation. Am J Med Genet A 2007, 143(3):271-276.

35. Veenma DC, Eussen HJ, Govaerts LC, de Kort SW, Odink RJ, Wouters CH, Hokken-Koelega AC, de Klein A: Phenotype-genotype correlation in a familial IGF1R microdeletion case. J Med Genet 2010, 47(7):492-498.

36. Walenkamp MJ, de Muinck Keizer-Schrama SM, de Mos M, Kalf ME, van Duyvenvoorde HA, Boot AM, Kant SG, White SJ, Losekoot M, den Dunnen JT, Karperien M, Wit JM: Successful long-term growth hormone therapy in a girl with haploinsufficiency of the insulin-like growth factor-I receptor due to a terminal 15q26.2-> qter deletion detected by multiplex ligation probe amplification. J Clin Endocrinol Metab 2008, 93(6):2421-2425

37. Ester WA, van Duyvenvoorde HA, de Wit CC, Broekman AJ, Ruivenkamp CA, Govaerts LC, Wit JM, Hokken-Koelega AC, Losekoot M: Two short children born small for gestational age with insulin-like growth factor 1 receptor haploinsufficiency illustrate the heterogeneity of its phenotype. J Clin Endocrinol Metab 2009, 94(12):4717-4727.

38. Boisclair YR, Rhoads RP, Ueki I, Wang J, Ooi GT: The acid-labile subunit (ALS) of the $150 \mathrm{kDa}$ IGF-binding protein complex: an important but forgotten component of the circulating IGF system. J Endocrinol 2001, 170(1):63-70

39. Domene HM, Hwa V, Jasper HG, Rosenfeld RG: Acid-labile subunit (ALS) deficiency. Best Pract Res Clin Endocrinol Metab 2011, 25(1):101-113.

40. Domene HM, Bengolea SV, Martinez AS, Ropelato MG, Pennisi P, Scaglia P, Heinrich JJ, Jasper HG: Deficiency of the circulating insulin-like growth factor system associated with inactivation of the acid-labile subunit gene. N Engl J Med 2004, 350(6):570-577.

41. Domene HM, Scaglia PA, Lteif A, Mahmud FH, Kirmani S, Frystyk J, Bedecarras P, Gutierrez M, Jasper HG: Phenotypic effects of null and haploinsufficiency of acid-labile subunit in a family with two novel IGFALS gene mutations. J Clin Endocrinol Metab 2007, 92(11):4444-4450

42. Heath KE, Argente J, Barrios V, Pozo J, az-Gonzalez F, Martos-Moreno GA, Caimari M, Gracia R, Campos-Barros A: Primary acid-labile subunit deficiency due to recessive IGFALS mutations results in postnatal growth deficit associated with low circulating insulin growth factor (IGF)-I, IGF binding protein-3 levels, and hyperinsulinemia. J Clin Endocrinol Metab 2008, 93(5):1616-1624

43. van Duyvenvoorde HA, Kempers MJ, Twickler TB, van Doorn J, Gerver WJ, Noordam C, Losekoot M, Karperien M, Wit JM, Hermus AR: Homozygous and heterozygous expression of a novel mutation of the acid-labile subunit. Eur J Endocrinol 2008, 159(2):113-120.

44. Fofanova-Gambetti OV, Hwa V, Kirsch S, Pihoker C, Chiu HK, Hogler W, Cohen LE, Jacobsen C, Derr MA, Rosenfeld RG: Three novel IGFALS gene mutations resulting in total ALS and severe circulating IGF-I/IGFBP-3 deficiency in children of different ethnic origins. Horm Res 2009, 71(2):100-110.
45. David A, Rose SJ, Miraki-Moud F, Metherell LA, Savage MO, Clark AJ, Camacho-Hubner C: Acid-labile subunit deficiency and growth failure: description of two novel cases. Horm Res Paediatr 2010, 73(5):328-334.

46. Bang P, Fureman A-L, Nilsson A-L, Bostrom J, Berit K, Ekstrom K, Hwa V, Grosenfeld R, Carlsson-Skwirut C: A novel missense mutation of the ALSIGF gene causing a L172F substitution in LRR6 is associated with short stature in two Swedish children homozygous or compound heterozygous for the mutation. Horm Res 2009, 72(suppl 3):86.

47. Gallego-Gomez E, Sanchez del Pozo J, Cruz Rojo J, Zurita-Munoz O, GraciaBouthelier R, Heath KE, Campos-Barros A: Novel compound heterozygous IGFALS mutation associated with impaired postnatal growth and low circulating IGF-I and IGFBP-3 levels. Horm Res 2009, 72(suppl 3):90-91.

48. Hales CN, Barker DJ, Clark PM, Cox LJ, Fall C, Osmond C, Winter PD: Fetal and infant growth and impaired glucose tolerance at age 64. BMJ 1991, 303(6809):1019-1022.

49. Barker DJ, Hales CN, Fall CH, Osmond C, Phipps K, Clark PM: Type 2 (non-insulin-dependent) diabetes mellitus, hypertension and hyperlipidaemia (syndrome $\mathrm{X}$ ): relation to reduced fetal growth. Diabetologia 1993, 36(1):62-67.

50. Parsons TJ, Power C, Manor O: Fetal and early life growth and body mass index from birth to early adulthood in 1958 British cohort: longitudinal study. BMJ 2001, 323(7325):1331-1335.

51. Morgan AR, Thompson JM, Murphy R, Black PN, Lam WJ, Ferguson LR, Mitchell EA: Obesity and diabetes genes are associated with being born small for gestational age: results from the Auckland Birthweight Collaborative study. BMC Med Genet 2010, 11:125

52. Gardes J, Bouhnik J, Clauser E, Corvol P, Menard J: Role of angiotensinogen in blood pressure homeostasis. Hypertension 1982, 4(2):185-189.

53. Ward K, Hata A, Jeunemaitre X, Helin C, Nelson L, Namikawa C, Farrington PF, Ogasawara M, Suzumori K, Tomoda S, Berrebi S, Sasaki M, Corvol P, Lifton RP, Lalouel JM: A molecular variant of angiotensinogen associated with preeclampsia. Nat Genet 1993, 4(1):59-61.

54. Zhang $X Q$, Varner M, Dizon-Townson D, Song F, Ward K: A molecular variant of angiotensinogen is associated with idiopathic intrauterine growth restriction. Obstet Gynecol 2003, 101(2):237-242.

55. Tower C, Chappell S, Kalsheker N, Baker P, Morgan L: Angiotensinogen gene variants and small-for-gestational-age infants. BJOG 2006, 113(3):335-339.

56. Pantel J, Machinis K, Sobrier ML, Duquesnoy P, Goossens M, Amselem S: Species-specific alternative splice mimicry at the growth hormone receptor locus revealed by the lineage of retroelements during primate evolution. J Biol Chem 2000, 275(25):18664-18669.

57. Dos Santos C, Essioux L, Teinturier C, Tauber M, Goffin V, Bougneres P: A common polymorphism of the growth hormone receptor is associated with increased responsiveness to growth hormone. Nat Genet 2004, 36(7):720-724.

58. Binder G, Baur F, Schweizer R, Ranke MB: The d3-growth hormone (GH) receptor polymorphism is associated with increased responsiveness to $\mathrm{GH}$ in Turner syndrome and short small-for-gestational-age children. J Clin Endocrinol Metab 2006, 91(2):659-664.

59. Blum WF, Machinis K, Shavrikova EP, Keller A, Stobbe H, Pfaeffle RW, Amselem S: The growth response to growth hormone (GH) treatment in children with isolated $\mathrm{GH}$ deficiency is independent of the presence of the exon 3-minus isoform of the GH receptor. J Clin Endocrinol Metab 2006, 91(10):4171-4174.

60. Carrascosa A, Esteban C, Espadero R, Fernandez-Cancio M, Andaluz P, Clemente M, Audi L, Wollmann H, Fryklund L, Parodi L: The d3/fl-growth hormone $(\mathrm{GH})$ receptor polymorphism does not influence the effect of $\mathrm{GH}$ treatment (66 microg/kg per day) or the spontaneous growth in short non-GH-deficient small-for-gestational-age children: results from a two-year controlled prospective study in 170 Spanish patients. J Clin Endocrinol Metab 2006, 91(9):3281-3286.

61. Carrascosa A, Audi L, Esteban C, Fernandez-Cancio M, Andaluz P Gussinye M, Clemente M, Yeste D, Albisu MA: Growth hormone (GH) dose, but not exon 3-deleted/full-length $\mathrm{GH}$ receptor polymorphism genotypes, influences growth response to two-year GH therapy in short small-for-gestational-age children. J Clin Endocrinol Metab 2008, 93(1):147-153

62. Wassenaar MJ, Dekkers OM, Pereira AM, Wit JM, Smit JW, Biermasz NR, Romijn JA: Impact of the exon 3-deleted growth hormone (GH) receptor polymorphism on baseline height and the growth response to recombinant human $\mathrm{GH}$ therapy in GH-deficient (GHD) and non-GHD 
children with short stature: a systematic review and meta-analysis. J Clin Endocrinol Metab 2009, 94(10):3721-3730.

63. Dörr HG, Bettendorf M, Hauffa BP, Mehls O, Rohrer T, Stahnke N, Pfäffle R Ranke MB: Different relationships between the first 2 years on growth hormone treatment and the d3-growth hormone receptor polymorphism in short small-for-gestational-age (SGA) children. Clin Endocrinol (Oxf) 2011, 75(5):656-660.

64. Hoffmann K, Heller R: Uniparental disomies 7 and 14. Best Pract Res Clin Endocrinol Metab 2011, 25(1):77-100.

65. Constancia M, Kelsey G, Reik W: Resourceful imprinting. Nature 2004, 432 (7013):53-57.

66. Silver HK, Kiyasu W, George J, Deamer WC: Syndrome of congenital hemihypertrophy, shortness of stature, and elevated urinary gonadotropins. Pediatrics 1953, 12(4):368-376.

67. Russell A: A syndrome of intra-uterine dwarfism recognizable at birth with cranio-facial dysostosis, disproportionately short arms, and other anomalies (5 examples). Proc R Soc Med 1954, 47(12):1040-1044.

68. Abu-Amero S, Monk D, Frost J, Preece M, Stanier P, Moore GE: The genetic aetiology of Silver-Russell syndrome. J Med Genet 2008, 45(4):193-199.

69. Kamp GA, Mul D, Waelkens JJ, Jansen M, Delemarre-van de Waal HA, Verhoeven-Wind L, Frolich M, Oostdijk W, Wit JM: A randomized controlled trial of three years growth hormone and gonadotropin-releasing hormone agonist treatment in children with idiopathic short stature and intrauterine growth retardation. J Clin Endocrinol Metab 2001, 86(7):2969-2975

70. Hitchins MP, Stanier P, Preece MA, Moore GE: Silver-Russell syndrome: a dissection of the genetic aetiology and candidate chromosomal regions. J Med Genet 2001, 38(12):810-819.

71. Kotzot D, Schmitt S, Bernasconi F, Robinson WP, Lurie IW, llyina H, Mehes K, Hamel BC, Otten BJ, Hergersberg M, Werder E, Schoenle E, Schinzel A: Uniparental disomy 7 in Silver-Russell syndrome and primordial growth retardation. Hum Mol Genet 1995, 4(4):583-587.

72. Eggermann T, Wollmann HA, Kuner R, Eggermann K, Enders $H$, Kaiser $P$, Ranke MB: Molecular studies in 37 Silver-Russell syndrome patients: frequency and etiology of uniparental disomy. Hum Genet 1997, 100(3-4):415-419.

73. Preece MA, Price SM, Davies V, Clough L, Stanier P, Trembath RC, Moore GE: Maternal uniparental disomy 7 in Silver-Russell syndrome. J Med Genet 1997, 34(1):6-9.

74. Gicquel C, Rossignol S, Cabrol S, Houang M, Steunou V, Barbu V, Danton F, Thibaud N, Le Merrer M, Burglen L, Bertrand AM, Netchine I, Le Bouc Y: Epimutation of the telomeric imprinting center region on chromosome 11 p15 in Silver-Russell syndrome. Nat Genet 2005, 37(9):1003-1007.

75. Netchine I, Rossignol S, Dufourg MN, Azzi S, Rousseau A, Perin L, Houang M, Steunou V, Esteva B, Thibaud N, Demay MC, Danton F, Petriczko E, Bertrand AM, Heinrichs C, Carel JC, Loeuille GA, Pinto G, Jacquemont ML, Gicquel C, Cabrol S, Le BY: 11 p15 imprinting center region 1 loss of methylation is a common and specific cause of typical Russell-Silver syndrome: clinical scoring system and epigenetic-phenotypic correlations. J Clin Endocrinol Metab 2007, 92(8):3148-3154

76. Schonherr N, Meyer E, Roos A, Schmidt A, Wollmann HA, Eggermann T: The centromeric $11 \mathrm{p} 15$ imprinting centre is also involved in Silver-Russell syndrome. J Med Genet 2007, 44(1):59-63.

77. Penaherrera MS, Weindler S, Van Allen MI, Yong SL, Metzger DL, McGillivray B, Boerkoel C, Langlois S, Robinson WP: Methylation profiling in individuals with Russell-Silver syndrome. Am J Med Genet A 2010, 152A(2):347-355

78. Eggermann T: Russell-Silver syndrome. Am J Med Genet C Semin Med Genet 2010, 154C(3):355-364

79. Georgiades P, Chierakul C, Ferguson-Smith AC: Parental origin effects in human trisomy for chromosome 14q: implications for genomic imprinting. J Med Genet 1998, 35(10):821-824.

80. Kotzot D: Maternal uniparental disomy 14 dissection of the phenotype with respect to rare autosomal recessively inherited traits, trisomy mosaicism, and genomic imprinting. Ann Genet 2004, 47(3):251-260.

81. Simon D, Leger J, Carel JC: Optimal use of growth hormone therapy for maximizing adult height in children born small for gestational age. Best Pract Res Clin Endocrinol Metab 2008, 22(3):525-537.

82. de Zegher F, Albertsson-Wikland K, Wollmann HA, Chatelain P, Chaussain JL, Lofstrom A, Jonsson B, Rosenfeld RG: Growth hormone treatment of short children born small for gestational age: growth responses with continuous and discontinuous regimens over 6 years. J Clin Endocrinol Metab 2000, 85(8):2816-2821.

83. Czernichow P: Treatment with growth hormone in short children born with intrauterine growth retardation. Endocrine 2001, 15(1):39-42.

84. Argente J, Gracia R, Ibanez L, Oliver A, Borrajo E, Vela A, Lopez-Siguero JP, Moreno ML, Rodriguez-Hierro F: Improvement in growth after two years of growth hormone therapy in very young children born small for gestational age and without spontaneous catch-up growth: results of a multicenter, controlled, randomized, open clinical trial. J Clin Endocrinol Metab 2007, 92(8):3095-3101.

85. Dahlgren J, Wikland KA: Final height in short children born small for gestational age treated with growth hormone. Pediatr Res 2005, 57(2):216-222

86. Carel JC, Chatelain P, Rochiccioli P, Chaussain JL: Improvement in adult height after growth hormone treatment in adolescents with short stature born small for gestational age: results of a randomized controlled study. J Clin Endocrinol Metab 2003, 88(4):1587-1593.

87. Ranke MB, Lindberg A, Cowell CT, Wikland KA, Reiter EO, Wilton P, Price DA: Prediction of response to growth hormone treatment in short children born small for gestational age: analysis of data from KIGS (Pharmacia International Growth Database). J Clin Endocrinol Metab 2003, 88(1):125-131.

88. US Food and Drug Administration: FDA Drug Safety Communication: Ongoing safety review of recombinant human growth hormone (somatropin) and possible increased risk of death. Available at: http://www. fda.gov/Drugs/DrugSafety/ucm237773.htm\#ds. Accessed February 15, 2012

89. Sperling MA: Long-Term Therapy with Growth Hormone: Bringing Sagacity to SAGHE. J Clin Endocrinol Metab 2012, 97(1):81-83.

90. Rosenfeld RG, Cohen P, Robison LL, Bercu BB, Clayton P, Hoffman AR, Radovick S, Saenger P, Savage MO, Wit JM: Long-term surveillance of growth hormone therapy. J Clin Endocrinol Metab 2012, 97(1):68-72.

91. Wilton P, Mattsson AF, Darendeliler F: Growth hormone treatment in children is not associated with an increase in the incidence of cancer: experience from KIGS (Pfizer International Growth Database). J Pediatr 2010, 157(2):265-270.

92. Bell J, Parker KL, Swinford RD, Hoffman AR, Maneatis T, Lippe B: Long-term safety of recombinant human growth hormone in children. $J$ Clin Endocrinol Metab 2010, 95(1):167-177.

93. Luger A, Feldt-Rasmussen U, Abs R, Gaillard RC, Buchfelder M, Trainer P, Brue T: Lessons Learned from 15 Years of KIMS and 5 Years of ACROSTUDY. Hormone Res Paediatrics 2011, 76(suppl 1):33-38.

94. Loftus J, Heatley R, Walsh C, Dimitri P: Systematic review of the clinical effectiveness of genotraopin (somatropin) in children with short stature. J Pediatr Endocrinol Metab 2010, 23(6):535-551.

95. Ergun-Longmire B, Mertens AC, Mitby P, Qin J, Heller G, Shi W, Yasui Y, Robison LL, Sklar CA: Growth hormone treatment and risk of second neoplasms in the childhood cancer survivor. J Clin Endocrinol Metab 2006, 91(9):3494-3498.

doi:10.1186/1687-9856-2012-12

Cite this article as: Saenger and Reiter: Genetic factors associated with small for gestational age birth and the use of human growth hormone in treating the disorder. International Journal of Pediatric Endocrinology 2012 2012:12.

\section{Submit your next manuscript to BioMed Central and take full advantage of:}

- Convenient online submission

- Thorough peer review

- No space constraints or color figure charges

- Immediate publication on acceptance

- Inclusion in PubMed, CAS, Scopus and Google Scholar

- Research which is freely available for redistribution 